3-14-2018

\title{
Organizing Under Austerity: How Residents' Concerns Became the Flint Water Crisis
}

Amy Krings

Loyola University Chicago, akrings@luc.edu

Dana Kornberg

The University Of Michigan

Erin Lane

The University Of Michigan

Follow this and additional works at: https://ecommons.luc.edu/socialwork_facpubs

Part of the Social Work Commons, and the Water Resource Management Commons

\section{Author Manuscript}

This is a pre-publication author manuscript of the final, published article.

\section{Recommended Citation}

Krings, Amy; Kornberg, Dana; and Lane, Erin. Organizing Under Austerity: How Residents' Concerns Became the Flint Water Crisis. Critical Sociology, , : 1-15, 2018. Retrieved from Loyola eCommons, Social Work: School of Social Work Faculty Publications and Other Works, http://dx.doi.org/10.1177/

0896920518757053

This Article is brought to you for free and open access by the Faculty Publications and Other Works by Department at Loyola eCommons. It has been accepted for inclusion in Social Work: School of Social Work Faculty Publications and Other Works by an authorized administrator of Loyola eCommons. For more information, please contact ecommons@luc.edu.

\section{(c) $(1) \ominus$}

This work is licensed under a Creative Commons Attribution-Noncommercial-No Derivative Works 3.0 License.

(C) The Authors 2018 


\title{
Organizing Under Austerity: How Residents' Concerns Became the Flint Water Crisis
}

Amy Krings Loyola University Chicago, USA

Dana Kornberg University of Michigan, USA

Erin Lane University of Michigan, USA

\begin{abstract}
What might it take for politically marginalized residents to challenge cuts in public spending that threaten to harm their health and wellbeing? Specifically, how did residents of Flint, Michigan contribute to the decision of an austerity regime, which was not accountable to them, to spend millions to switch to a safe water source? Relying on evidence from key interviews and newspaper accounts, we examine the influence and limitations of residents and grassroots groups during the 18-month period between April 2014 and October 2015 when the city drew its water from the Flint River. We find that citizen complaints alone were not sufficiently able to convince city officials or national media of widespread illness caused by the water. However, their efforts resulted in partnerships with researchers whose evidence bolstered their claims, thus inspiring a large contribution from a local foundation to support the switch to a clean water source. Thus, before the crisis gained national media attention, and despite significant constraints, residents' sustained organization — coupled with scientific evidence that credentialed local claims - motivated the return to the Detroit water system. The Flint case suggests that residents seeking redress under severe austerity conditions may require partnerships with external scientific elites.
\end{abstract}

\section{Introduction}

On April 25, 2014, after nearly 50 years of purchasing Lake Huron water from the City of Detroit, Michigan, the City of Flint, Michigan, began to pump inadequately treated water from the Flint River into residents' homes. The results, as we know now, were disastrous. Residents immediately noticed discolored and foul-smelling liquid coming from their taps. Reports of rashes, hair loss, and respiratory illnesses soon followed, and later blood lead levels in children spiked. The decision to switch to the Flint River water was made while the city was controlled by an austerity-driven emergency manager (EM) who was mandated to cut city expenses and had the political power to dispense with elected city leadership, which severely limited Flint residents' recourse when their water quality dramatically declined. While local media covered residents' concerns, the national media did not provide sustained attention until late 2015, following the switch back to the Detroit system.

How did Flint residents and grassroots groups contribute to a switch back to the safer, yet more expensive, Detroit water system 18 months later in October 2015? Within this economically and politically constrained context, Flint residents - a majority of whom were poor and African American - questioned officials, protested, and organized themselves while officials discredited, minimized, and ignored their claims. However, 
local efforts led to support from credible institutions with the capacity to document and disseminate evidence of the contaminated water and its dangerous health effects. This scientific evidence led to a large donation from a local philanthropic institution and, ultimately, the switch back to the Detroit water system. The Flint water case moves studies of austerity politics beyond locating the character and impacts of neoliberal policies to understanding how they might be contested by attracting resources that are perceived as credible by neoliberal austerity regimes.

\section{Urban Austerity and the Erosion of Local Accountability}

A central feature of neoliberal governance in the United States has been the production of austerity conditions in cities. Jamie Peck (2012) has described how urban austerity regimes emerge through processes of scalar dumping, whereby financial responsibility for public goods is passed down from national to state and local governments. The logical priority that scalar dumping sets in motion is clear: cash-strapped cities must either raise revenue through taxes, fees, or service costs for public goods or they must cut spending (Birkenholtz, 2010; Copeland, 2012). Scalar dumping disproportionately strains cities like Flint, which have already suffered severely because of deindustrialization, residential abandonment, aging infrastructure, high poverty rates, and racial segregation. Thus, although a city's municipal budget is shaped by a range of economic factors beyond the control of city leaders, financial hardships tend to be borne by residents.

When cities fail to be self-sufficient, officials may employ legal tools such as emergency management laws to label budget shortfalls as financial "emergencies." This characterization can provide justification for punitive intervention-including democratic curtailment coupled with cuts to public services - by higher levels of government (state, national, or international) (Hayes, 2017). Thus, austerity is indeed a "politically imposed condition" (Peck, 2012: 637). Additionally, by characterizing the city as experiencing a fiscal emergency, policies that entail additional public spending are removed from contention and effectively blocked from the political agenda. And by focusing on the short-term alleviation of fiscal problems, longer-term structural problems - such as the loss of revenue due to a declining tax base, decreases in state revenue sharing, and growing unemployment - are cast outside the sphere of public debate (Desan and Steinmetz, 2015; Fasenfest and Pride, 2016).

Despite Michigan's history as a labor movement stronghold, the state's recent political and demographic changes have made it ripe for neoliberal policies that emphasize local austerity measures, including emergency management, as antidotes to economic problems. Michigan has been one of 16 US states with a provision for the state government to shift local decisionmaking authority away from elected city leaders to an appointed EM under conditions of financial distress (see Scorsone, 2014). The EMwhose job is to balance the city's budget without raising taxes or renegotiating debt with creditors-is accountable to the governor and State Treasury Department officials rather than to city council members, thereby reducing opportunities for citizen groups to influence local policies (Lee et al., 2016). This has further consolidated the Republican- 
held state government's power, while weakening the Democrat-majority city governments.

Social action is increasingly necessary to counter the dangerous effects of austerity policies, yet the possibilities for democratic influence have been severely curtailed. Additionally, as environmental regulatory rules are relaxed, "the operating principle is that toxic chemicals are presumed innocent of harming human health unless proven guilty" (Gibbs, 2002: 103).

In this article, we demonstrate how a curtailed public sphere presented severe challenges for Flint residents who organized to gain redress for their contaminated drinking water. Taking the October 2015 switch back to Detroit water as a significant, if severely belated win, we ask what might it take for those who suffer most under austerity regimes to effectively secure policies that support public spending and local decision-making authority? We find that shifting the politics of discredit is especially important because austerity regimes are able to rapidly dispel residents' claims by challenging their credibility.

\section{Research Design}

The Flint water crisis was produced by a series of political decisions rooted in a logic of austerity and driven by a desire to cut municipal spending in a political context without local democratic accountability. A retrospective look is useful for revitalizing the idea that history could have happened differently and understanding why events unfolded when and how they did.

To trace how the politics of credibility shifted between the decision to switch the city's water source in April 2014 until October 2015, when the city returned to Detroit water, we created a database of 329 Flint Journal/MLive articles published between January 2010 and July 2016, which we located through Newsbank, using the search terms "Flint River" and "pipes," "pipeline," or "rates." We triangulated our data by reviewing national media coverage from the same time period and original sources, including internal documents that were released by Governor Rick Snyder's administration after the contamination was exposed. We also interviewed a Flint Journal reporter, a grassroots activist, an investigative reporter from the American Civil Liberties Union (ACLU) of Michigan, and the president of the Flint-based Mott Foundation. Our respondents were identified because of their ability to explain when and how citizen organizing was able to secure institutional alliances or persuade officials. Finally, we took original field notes at key public events in which residents described how they came to question public officials and, ultimately, press them to take their demands seriously. Our strategy of focusing on local media coverage in addition to primary sources provides the benefit of more complete coverage, as the Flint Journal followed the story in-depth from its beginning.

As part of our analysis, we looked for spaces of resistance, particularly examples of how citizen groups were able to suggest alternatives to city and state discourses of austerity. 
We coded the database to track the ways in which the credibility of city and state institutions, officials, residents, and scientists was strengthened or challenged.

\section{The Flint Water Crisis and Local Influence}

Between 2011 and 2015, Flint was placed under emergency management, and four consecutive EMs were appointed by Michigan Governor Rick Snyder to balance the city's budget by cutting expenditures. Among these expenditures were those for Flint's water source: while Flint had, since 1967, purchased its drinking water from the Great Lakes Water Authority (formerly the regional Detroit Water and Sewerage Department), in 2012, Ed Kurtz, the first of Flint's four EMs, suggested that Flint join the new regional Karegnondi Water Authority (KWA), which was building its own pipeline to Lake Huron and would bring down costs (Lynch and Ramirez, 2016). The cost savings Kurtz promised were significant-\$5 million during the first year of service, $\$ 19$ million after eight years, and between $\$ 100$ and $\$ 300$ million over 25 years (Counts, 2016a, 2016b) and with these numbers, debate about whether to switch to the KWA was relatively shortlived. In April 2013, city leaders, including Kurtz, Mayor Dayne Walling, and the city council, agreed to join the KWA. The Flint City Council and many of its residents supported the KWA with the hope that it would lower water bills that were among the highest in the country (Longley, 2012).

However, because construction of the KWA would not be completed for two years after Flint's contract with Detroit was set to expire, the city needed a plan to supply water in the interim. Pressure on the EM to cut costs coupled with the impending end of the Detroit contract led to hasty decisions, with minimal regulatory oversight or citizen input. Flint's second EM, Darnell Earley, proposed that, by temporarily drawing its own water from the Flint River, the city could avoid two years of paying for the expensive Detroit water. Because of the EM, this decision did not require a vote by city council and likely would not have received public support given the widespread perception that the river was contaminated by decades of industrial waste (Longley, 2011). Nonetheless, Major Walling announced the decision to change Flint's water source to the public with little warning in March 2014: "In less than 50 days," he declared, "Flint residents will begin drinking water from the Flint River" (Adams, 2014a). Due to cost and time constraints, upgrades needed for the water plant were severely underfunded: four months before the switch, the city had spent just \$3.8 million (Adams, 2014b), even though a 2011 Rowe Engineering report had estimated that around $\$ 60$ million in upgrades were required to make the river treatment plant a safe, full-time source of drinking water (Longley, 2011). Despite these difficulties, on April 25, 2015, city and state officials raised glasses of water to celebrate as water began to flow from the Flint River.

\section{Residents Question Water Safety While Officials Minimize Concerns}

The consequences of the swift undemocratic process by which the city switched to Flint River water were almost immediately apparent: residents complained that their water was discolored, bad tasting, and foul smelling. As the water quality worsened, residents had few outlets to report their problems because the city council had limited authority and the 
Office of the Ombudsman had been eliminated. When complaints about the water quality were made, representatives of the agencies charged with monitoring the safety of the water - the Michigan Department of Environmental Quality (MDEQ) and the Flint Department of Public Works - sought to reassure the public. Officials of MDEQ acknowledged that the river water was different from Detroit's Lake Huron source, but denied any serious problems, reporting that the water met "all quality standards set by the state" (Fonger, 2014a). Department of Public Works Director Howard Croft asked residents to be patient, acknowledging how hurried the process had been: "city water plant workers have had a crash course in learning how to treat river water" (Fonger, 2014b). Residents whose water was discolored remained skeptical of MDEQ's assurances, and while some began to purchase bottled water and filters, many did not have the means and continued to drink, cook with, and bathe in the city water. In an early protest, some residents brought bottles of their discolored water to City Hall, but their actions were largely ignored or framed as unfounded.

The Flint-based Democracy Defense League (DDL), which was established in 2011 to oppose the state's emergency management law, provided early support to residents who were concerned about the water quality. For years prior to the switch, the volunteer members of the group met to educate Flint residents about the authority that the state law granted to EMs to amend collective bargaining contracts, cut or privatize city services, and sell off public assets without local input (N. Shariff, personal communication, March 22, 2017). The Democracy Defense League, which employed a race- and class-based analysis of the emergency management system and its impacts, sought to "confront fascism by challenging our local dictator" (N. Shariff, personal communication, March $22,2017)$. Consequently, when residents complained about their expensive and undrinkable water, members of the DDL were prepared to document concerns, frame them as a consequence of emergency management, and pressure city leaders to stop charging residents high water rates for a product that they could not use. However, these concerns were also largely dismissed, in part because officials questioned the credibility of people who had been protesting emergency management and its impacts for years. As Flint Journal reporter Ron Fonger explained: “There's John Smith. He was protesting the garbage company contract and now he's protesting the water" (personal communication, February 23, 2017). Moreover, because not everyone was impacted to the same degree, there was skepticism that protesters' complaints were exaggerated (N. Shariff, personal communication, March 22, 2017)—which served not only to discredit protesters, but also to further deprive them of avenues toward redress.

While the concerns of residents were largely dismissed, when the leadership of General Motors (GM) noticed a decline in its water quality, state leaders took those concerns seriously. In October 2014, six months after the switch, the company announced that it had negotiated a deal to return to the Detroit system because the Flint River water was corroding car parts within its Flint manufacturing plant (Fonger, 2014c). This solution allowed the corporate entity to opt out of the water system, but did nothing to transform the system overall. 
Unlike GM, however, neither Flint residents nor the city council elected to represent them had the power to maneuver around the EM's decision. The city council had been largely disempowered by the emergency management laws, and though some of its members began to suggest abandoning the Flint River, it had no authority to approve a switch back to Detroit. Flint City Council members such as Monica Galloway questioned whether state officials were taking concerns about human health seriously and, at the same time, made it clear that the emergency management structure had circumvented the council's democratic mandate: "This is just another thing that says to me (that) we are like guinea pigs ... It's like a research project ... that we would normally do on rats" (Fonger, 2014c). In fact, while officials eventually determined that the metal corrosion of GM car parts was the result of high levels of chloride - the same chemical later recognized as the source of corroding lead service pipes - state and city regulators failed to raise concerns about the potential harm to residents' health. Furthermore, critics have noted that the decision to allow GM to change its water source represented a missed opportunity for national media to take up the Flint water crisis. In fact, national media remained largely silent on the issue until December 2015-two months after the switch back to Detroit's water system following Mayor Karen Weaver's declared state of emergency.

The GM decision revealed how this politics of credibility is rooted in racial biases. Some Flint residents explicitly named and confronted this bias, particularly after the city issued a public warning in January 2015 that the water contained high levels of total trihalomethanes (TTHMs), carcinogenic byproducts of chemicals used to combat the prior bacteria outbreak, which can cause permanent damage to the kidneys, liver, and nervous system (Fonger, 2015a; Olson, 2016). During a January 2015 public meeting, a Flint woman castigated public officials: "Look at that water! ... None of you white people would drink that water" (Carmody, 2015a). Mayor Walling, who is white, tried to reassure the audience: "The city water is safe to drink. My family and I drink it and use it every day" (Carmody, 2015b).

The city's TTHM notice helped explain why the water tasted and smelled like chemicals. However, it also revealed that officials knew of the TTHM problem as early as May 2014, which incensed many residents and caused them to question officials' credibility and care for their wellbeing (Fonger, 2015a). During that time period, residents had likened the taste and smell of the water to an over-chlorinated swimming pool. Some reported that their hair was falling out, and resident Amber Hasan complained that her eyes would burn while showering and that she had trouble seeing afterwards (L. Smith, 2016b). Local journalist Ron Fonger described how officials' lack of concern caused him to question the credibility of official reassurances: "TTHMs are a reason that you ought to be concerned ... And why do we have these high levels of TTHMs when we never had them when we were on Detroit water?" (R. Fonger, private communication, February 23, 2017).

State officials, including MDEQ Director Steve Busch, began to take a different rhetorical approach to minimize the water problems. Busch began to acknowledge that there were health concerns, but he framed them as individual rather than widespread 
troubles. By underplaying government accountability, he urged residents to take personal responsibility: "Is there a risk in the short term? That depends on you ... It's an individual thing ... . You can make a judgment (after talking to your doctor)" (Fonger, 2015a). Individuals and institutions with the resources to do so began to take their own precautions. Flint Head Start programs stopped using city water, and it was later discovered that state leaders arranged to have purified water delivered for employees at Flint's State Office Building (Egan, 2016). In January 2016, the University of MichiganFlint independently tested for lead on its campus and found contaminated water (Schuch, 2015). In retrospect, this too should have been cause for more rigorous and widespread testing. Instead, the university shut down drinking fountains on that part of campus. Like GM, these institutions were able to remove themselves from the city's water system. Meanwhile, residents like Claire McClinton, a local leader of DDL, expressed deep incredulity: "We survived bacteria. We've had boil water advisories as a result. They put too much chloride in the water, we've got trihalomethanes, and it's just been one disaster after another ... I mean, what do we have to do to get them to turn the water back on to Detroit?" (L. Smith, 2016b).

\section{Flint Residents Discover Lead}

A series of events that began with resident LeeAnne Walters was unfolding that would produce a new public health concern: lead contamination. Following the switch to the Flint River, the water in Walters's home was consistently discolored, and her children were becoming sick after swimming in the family pool. Walters called Flint's utilities technician, Mike Glasgow, to test the water in her home. After he found extremely high lead levels, Glasgow instructed Walters to prevent her family members from drinking, swimming, or bathing in the water. Glasgow continued to test the water at the Walters home on a weekly basis and found that the amount of lead was steadily increasing. Walters, who was better off financially than many of her fellow residents, had the health insurance and transportation necessary to take her children to a medical specialist in a nearby city, and one of them was diagnosed with lead poisoning (L. Smith, 2015).

Although Glasgow took the Walters's case seriously, higher level city and state officials characterized the lead in her water as an outlier rather than a systemic problem. Blaming the lead in her home's outdated pipes, officials again resorted to the neoliberal idea of individual over public responsibility, thereby avoiding responsibility for a systemic intervention. The city's fourth EM, Jerry Ambrose, focused on tests showing the city's water to be safe, insisting that the "city water now [was] within all acceptable guidelines" and claiming that any issues were short-term matters of aesthetics that the city could

quickly resolve (Fonger, 2015b). Opportunities for widespread testing, which could have resulted in earlier intervention, were ignored. Ambrose maintained that a switch back to the Detroit system was out of the question because of its high cost - a decision that accords with his austerity mandate, which required increased spending in one area to necessitate cuts in another. Thus, at the very moment that citizen concerns were crystallizing into a demand to switch back to the Detroit water system, the EM maintained that Flint would continue to draw its water from the Flint River until the KWA line was completed. 
LeeAnne Walters, however, did not believe officials when they said that the lead had come from her home's individual plumbing. Her home had plastic pipes; the culpable source had to be the water system itself. Walters's outrage about the harm to her children began to take aim at public officials: "After the fact, knowing I was giving this to my kids makes me sick, because we should be able to trust the fact that we're paying for this service and we should be able to trust the fact that it's not going to harm our kids" (L. Smith, 2016b). Walters's belief that public officials were misleading residents in a way that could jeopardize the health of other children led her to reach out to scientists who could test and verify the scope of lead contamination in Flint's water system.

\section{Alliances with Scientists and the Collection of Credible Evidence}

Sustained grassroots pressure eventually contributed to the switch back to Detroit's safe water supply, but public concerns alone were insufficient due to the severely curtailed public sphere. Ultimately, residents like LeeAnne Walters and grassroots groups such as the DDL had to ally themselves with national activists, government employees, academics, and scientists in order to amass evidence of their grievances that would be deemed credible by government institutions. This was necessary in order to counter claims of the state power structure, including the EM and MDEQ, who sought to reassure the public while discrediting their concerns. Living under an austerity regime that would allow for neither additional municipal spending nor democratic opposition meant that concerns about the water's safety were both deprioritized and delegitimized.

Consequently, residents and private actors became responsible for documenting and responding to a burgeoning public health crisis.

There were several major shifts in local organizing strategies and tactics over the course of the crisis that strengthened the credibility of citizen claims against the state. First, residents and grassroots groups began to understand that the problems they had each discovered were connected and caused by a flawed system. Melissa Mays, who joined with LeeAnne Walters to form the grassroots group Water You Fighting For?, described this process: "First, we had to get residents organized and demonstrate that we weren't crazy. Second, we had to convince ourselves that we deserve better" (M. Mays, private communication, March 7, 2017). This growth in confidence that residents' concerns were valid was particularly necessary to combat official efforts to discredit, minimize, or ignore complaints.

Second, existing grassroots groups including the DDL and Concerned Pastors for Social Action, a coalition of faith leaders, began to focus on Flint's water problems, joining with emerging groups like Water You Fighting For? to establish the Flint Coalition for Clean Water. By incorporating multiple groups within a single coalition, members could simultaneously address immediate health concerns and continue to advocate for a return to the Detroit system. For example, in April 2016, the coalition sought legal action against the city and began to document complaints about the water and related medical issues (Nagl, 2015). Meanwhile, the Concerned Pastors for Social Action worked to 
distribute donated bottled water and filters to residents who could not afford them while demanding a shift in the water source.

The third notable shift included efforts to secure the support of national activists, government employees, and scientists, whose credentials and institutional affiliations would lend greater credibility and legitimacy to residents' growing concerns. LeeAnne Walters, who had grown increasingly wary of reassurances provided by MDEQ and city officials, was particularly active in this effort. Notably absent from this group, however, were national media outlets, which did not reliably cover the water problems in Flint until December 2015 - two months after the switch back to the Detroit water system (Jackson, 2017).

Residents reached out to environmental activist Erin Brockovich, who sent national water quality expert Robert Bowcock to independently test Flint water. Following a public march and rally on a cold February day, Bowcock reported his findings: "Every time [Flint water officials] had a problem, they threw another chemical at it" (Fonger, 2015c). The discovery of high chemical use strengthened the credibility of residents when they complained about the water burning their eyes, causing their hair to fall out, and smelling like a swimming pool. His findings began to chip away at city and state officials' reassurances to the public and to undermine their credibility.

The Bowcock report, along with increasing citizen pressure, paved the way for new alliances with public officials, including the city council and EPA. Under the emergency management law, elected city council members had limited legal authority; however, in March 2015, they took a symbolic vote to "do all things necessary" to reconnect to the Detroit water (M. Smith, 2015). The EM responded by digging in his heels and reiterating that the city would not return to the Detroit system. Instead, he established two water advisory committees and hired external consulting firm Veolia to assess the city's water testing and distribution practices.

When Veolia's tests concluded that Flint's water met all state and federal safe drinking standards, residents and some city council representatives were not convinced. These claims were not supported by their lived experiences. Thus, Flint council members and residents began to express their distrust more overtly, directly challenging the credibility of city and state officials. Council Member Kerry Nelson responded with open defiance: "I will not tell any of the residents I represent to drink the water" (Fonger, 2015d). Resident Jacqueline Hill was indignant, accusing officials of deceit: "We have been getting people telling us the water is fine, but when I cut my tap on, it still smells ... This water is not fine. You all are lying to us" (Fonger, 2015e).

Walters, meanwhile, was growing more suspicious that the city and state's reassurances would cause other Flint children to be poisoned by lead. After the strategic partnership with Brockovich and Bowcock, she continued to seek out legitimizing institutions and allies who could independently test the water. In the first of several alliances that would prove crucial to uncovering the extent of the lead contamination, Walters contacted the US Environmental Protection Agency (EPA) groundwater and drinking water regulation 
manager Miguel Del Toral to report the extraordinarily high levels of lead that city water testers had found in her home. Del Toral visited the Walters's home and became alarmed by the dangerously high levels of lead that he found. He followed up with MDEQ for answers and, like Walters, grew concerned that state officials were not properly treating or monitoring the Flint water. In a letter to MDEQ and EPA officials, Del Toral argued that reassurances from MDEQ were dangerous because they "could provide a false sense of security to the residents of Flint regarding lead levels in their water and may result in residents not taking necessary precautions to protect their families from lead in water" (Del Toral, 2015). He then leaked this letter to Walters, who shared it with other residents, reporters, and investigative journalist Curt Guyette of the Michigan ACLU, who had been chronicling the impacts associated with emergency management throughout the state (L. Smith, 2016a).

While attention to Flint's water contamination was rising - and so too the legitimacy of the residents' complaints - the leaked Del Toral letter proved pivotal because it was the first time that someone in an official capacity attested to the veracity of residents' concerns. Local reporters turned to MDEQ for answers, putting the department on the defensive. Brad Wurfel, spokesman for MDEQ, tried to quickly dispel these concerns: "Let me start here - anyone who is concerned about lead in the drinking water in Flint can relax" (L. Smith, 2015). Wurfel reasoned that Flint's water quality was no different than Detroit's or any other city's, and he suggested that anyone with a house more than 30 years old could contact the city to have their water tested (L. Smith, 2015). Wurfel employed the same dismissive rhetoric previously used by the MDEQ director to convert widespread concerns into personal problems that required individual responsibility.

With the leaked Walters memo, concerns about the water quality were rising, and pressure on MDEQ and the governor's office was growing. Still, concerns about Flint's water quality had not earned sufficient cachet to contest the austerity regime and force a switch back to the Detroit water. A trickle of national media outlets covered stories on Flint's water between March and October of 2015, but the story was not yet national headline news (Jackson, 2017). Thus, residents, including LeeAnne Walters, continued to build strategic alliances that would help to strengthen the legitimacy of their claims while their sustained pressure got the attention of other partner advocates. In August 2015, at Del Toral's suggestion, Walters called Marc Edwards, an engineering professor at Virginia Tech who had gained a reputation for exposing lead contamination in Washington, DC's water supply (Lurie, 2016). Walters mailed water samples from her home to Edwards who, like Del Toral, was shocked by the high levels of lead contamination. In response, Edwards and some of his students traveled to Flint to collaborate with the Flint Rising Coalition and its grassroots members including Concerned Pastors for Social Action, Water You Fighting For?, and the Democracy Defense League. Together, the Virginia Tech team and leaders from the Flint community trained citizen volunteers, who systematically collected more than 300 water samples across the city. The Virginia Tech-Flint Water Study test results substantiated local concerns: lead levels were roughly two times higher than city tests had indicated (Guyette, 2015a). Edwards was able to explain the difference in the findings by detailing how the city's water testers intentionally flushed out pipes before collecting samples and 
avoided sampling homes that had lead service lines (Brush, 2015; Guyette, 2015b). These findings, coupled with the discovery that MDEQ and the city had relaxed testing rules, further unseated official regulatory bodies as trusted authorities.

Although representatives from MDEQ and the EPA acknowledged the results of the Virginia Tech-Flint Water Study behind closed doors, state officials were still publicly reassuring residents while discrediting Edwards and his results. In an internal email, state officials described how the study was "putting added pressure" on MDEQ and that any delay for corrosion control treatment "would likely cause even higher levels of lead" (Spangler, 2016). In public, however, representatives of MDEQ, the EPA, and the governor's office characterized residents as hysterical; Del Toral (who had been removed from the Flint case due to leaking his memo) as a "rogue" employee; and Edwards as an academic whose warnings about lead should be questioned because, according to MDEQ spokesperson Brad Wurfel, he and his Virginia Tech research team were known to "pull that rabbit out of that hat everywhere they go" (L. Smith, 2016a; M. Smith, 2016). Still, even while they asserted that residents had nothing to fear, the strength of their rhetoric suggests an acknowledgement that institutional forces had begun to ally against them, and MDEQ - in a significant shift — quietly told Flint officials to improve their water treatment system to reduce exposure to lead from plumbing in homes (Fonger, 2015f).

The echoes of residents' protests eventually made their way into the hallways of local institutions. In early October 2015, the credibility of their charges was further bolstered when Mona Hanna-Attisha, director of Flint's Hurley Medical Center Pediatric Residency Program, released a study that revealed a statistically significant increase in blood lead levels of children. Hanna Attisha found that the areas of Flint with the highest lead levels in household water, as identified by the Virginia Tech-Flint Water Study, were also where the most dramatic increases in infant and children's blood lead levels occurred (Fonger, 2015g). She and the president of the Hurley Medical Center called for a return to the Detroit water system.

Once again, state officials responded to these contradictory findings and calls for a switch back to Detroit water by questioning the legitimacy of the results. In an internal memo, Dennis Muchmore, the governor's chief of staff, continued to characterize residents as irrational: "we have the anti-everything group turning to the lead content which is a concern for everyone, but DEQ and DHHS [Department of Health and Human Services] and EPA can't find evidence of a major change ... Of course, some of the Flint people respond by looking for someone to blame instead of working to reduce anxiety" (Bosman et al., 2016). Despite the backlash, Hanna-Attisha stood by her findings and, on October 1, 2015, the Michigan Department of Health and Human Services confirmed that blood lead levels in children and infants had indeed spiked.

Although pressure had been building for some time, Hanna-Attisha's findings were widely credited as the catalyst for other institutions, most notably the Flint-based Mott Foundation, to provide the economic and political resources that finally pushed Governor Snyder to allow the city of Flint to return to the Detroit water system. Ridgway White, president of the Mott Foundation, explained how Hanna-Attisha's report convinced him 
and the foundation's board members to donate $\$ 4$ million to subsidize the cost of the switch. Although Mott staff had previously complained internally about the water quality, with the documentation provided by Hanna-Attisha, he explained: "We had the data for me to be able to call the governor and say, 'Hey, this is our hometown ... We're here to help"' (personal communication, March 22, 2017). The Mott donation, coupled with the $\$ 2$ million from the city, permitted state legislators to avoid accusations that the state funds amounted to a "bailout," which was likely to draw backlash from suburban rural white legislators whose constituents tend to oppose funding for majority-black Michigan cities.

The widespread acceptance and dissemination of Hanna-Attisha's results, which demonstrated a clear rise in child lead poisoning, were facilitated by her status as a medical doctor, which meant that not only was she "credentialed," but she was perceived as neutral in a way that residents with discolored bottles, skin rashes, and clumps of hair were not. Further, because the findings complemented those of the Virginia Tech-Flint Water Study, the body of credible evidence began to tilt in favor of those who warned of the water's danger. As journalist Ron Fonger explained, "All of a sudden, we went from having [residents] saying, 'something is wrong with the water' to having some nationally recognized people saying, 'Yes, this water is a mess. Here's what's happening and here's why it's happening"” (private communication, February 23, 2017). He continued: "The final blow that knocked over this whole house of cards for the State and the City ... was when Dr. Mona came out with her study ... It's like the whole institution of Flint shifted" (private communication, February 23, 2017).

Thus, it was the evidence collected by credentialed experts, combined with financial incentives from the Mott Foundation that led Governor Snyder to allow Flint to return to the Detroit water system on October 16, 2015. Nevertheless the damage was done. After 18 months of drawing its water from the Flint River, a new public health emergency multiplied Flint's existing fiscal crises and resulted in the betrayal of citizen trust.

\section{Discussion}

Financial constraints, together with limited options for citizen opposition, motivated a series of decisions that culminated in the Flint water crisis. This cost-cutting austerityregime imperative rushed a change in the water supply before treatment plant workers and safety mechanisms were prepared and resulted in insufficient treatment and monitoring of the Flint River water. When residents complained about their poor water quality, a series of EMs asserted that any alternative to the Flint River source would be cost prohibitive. However, following three boil water advisories, the discovery of TTHM in the water, and General Motors' change to the Detroit system due to corroding car parts, residents continued to mobilize and call for a return to the safer yet more expensive Detroit water system.

The people of Flint - like many of those affected by austerity measures - were disadvantaged by systemic racism and classism and were thus at high risk of having their statements and experiences discredited. Officials responded to complaints by framing 
water issues as temporary and by characterizing health problems as individualized, thus suggesting the response of personal medical care rather than investments in public infrastructure. Because the usual pathways to local accountability were foreclosed by emergency management, when Flint's city council voted to do "everything in its power" to force a switch back to the Detroit water system in March 2015, the EM was empowered to ignore their wishes. Further, as national media failed to cover the unfolding health crisis in Flint, citizen claims were largely ignored. Citizen influence was thus triply limited: first by the dominance of the cost-savings mandate, second by an autocratic regime in which EMs were able to make decisions without formal accountability to local citizens, and third by national media that "utterly failed to capture and depict all the agency and self-empowerment of the populace to speak for themselves" (Jackson, 2017).

Given these economic, political, and social constraints, how did Flint residents contribute to the change in their water source? The switch back to Detroit water happened, in part, because local efforts resulted in securing the support of credentialed people and institutions that used a quantitative language that is privileged within neoliberal logic. When presented with the body of evidence culminating from the Bowcock report, the Virginia Tech-Flint Water Study, and Hanna-Attisha, outside institutions-including the Mott Foundation - were moved to provide the additional political and economic resources necessary to finally facilitate a change back to the Detroit system. Even after the change in the water source, these data were used to inform belated national and international media attention.

Marc Edwards and Mona Hanna-Attisha, who were based at a nationally acclaimed university and a locally reputable hospital, respectively, made it possible for local residents' concerns to be taken seriously by regulatory institutions including the MDEQ. Their studies amplified residents' public claims by effectively translating them into the language of scientific expertise. Furthermore, their findings discredited official expertise by revealing that city and state workers had manipulated testing procedures to produce favorable results. The ability to "verify" what residents had described for months mattered for at least two reasons. First, following the release of HannaAttisha's study, the Mott Foundation became willing to subsidize the cost of the switch back to Detroit water through a \$4 million grant to the city of Flint. Second, following the switch, Mayor Karen Weaver declared a state of emergency with the goal of securing support to address local health impacts. This call, now bolstered by the Edwards and Hanna-Attisha data, provided evidence that national and international journalists began to take seriously. Had national media outlets credentialed the predominantly poor and black residents of Flint, rather than opting to trust predominately white officials' reassurances in the midst of local claims, it is likely that the state would have intervened earlier to switch back to Detroit water (see Jackson 2017). It was also important that the health issues being documented — ranging from short-term rashes to longer-term brain damage-were all ailments borne by children. In a 2016 community meeting, for example, water activist Laura Sullivan acknowledged that this helped their cause: "At first, community members who complained were portrayed as hysterical. This changed because kids were impacted" 
(L. Sullivan, private communication, March 7, 2016). Widely understood as innocent victims, children were likely to attract greater sympathy than adults.

Yet while Edwards and Hanna-Attisha have been characterized as the "heroes" of the Flint water crisis, their involvement would have been delayed - and perhaps not even possible - were it not for the sustained outcry of local residents-turned-activists and grassroots groups, whose groundswell of activity provided the information and pressure required to get the attention they needed. Ultimately, the change back to Detroit water required 'a diverse community — not just a few 'saviors' — who would not believe the lies that they were told" (C. Guyette, personal communication, March 7, 2016). Although experts' involvement proved necessary to motivate the switch back, their involvement was precipitated by residents "pushing, and pushing, and pushing who would not give up ... they were the driving force all along and continue to be" (C. Guyette, personal communication, March 17, 2017). As Nayyirah Shariff, a local organizer and the coordinator of DDL and Flint Rising Coalition, elaborated: "One of the most troubling things [following the switch back to Detroit water is] totally erasing the community's role and elevating external spokespeople. Like, Marc Edwards was not just a random person who just randomly showed up - there was a lot of work before that" (personal communication, March 17, 2017).

\section{Conclusion}

The decision to return to Detroit's water pipeline was a remarkable accomplishment, given the extreme budgetary and democratic limits put on the city. However, it must be noted that the political system that gave rise to the water crisis - the Michigan emergency management law (PA 436) - remains in place. Blame has been placed on employees of the city of Flint and of the state, but the system as a whole remains intact. As Clare McClintock of Democracy Defense League suggests, "This is a new model of governance that is dangerous and unacceptable. And it's spreading to a town near you" (private communication, March 7, 2016).

Permanent damage has been done to the city's water system, the health of Flint residents, and the degree of trust that residents are willing to grant government institutions. Further, the health impacts of drinking unsafe water will continue to affect residents for years. Although residents and their supporters have demonstrated incredible fortitude in waging a protracted struggle for safe and affordable water, the lack of corrosion control in Flint has resulted in the deterioration of public infrastructure. Flint has now received federal and state funding to assist with pipe replacement, health, and education; the EPA's lead and copper rule is under review; and some public officials have been charged with crimes including involuntary manslaughter - all of which is necessary to begin repairing physical harm and preventing similar situations from happening elsewhere. More difficult to repair, however, is residents' trust in their institutions. From local emergency management curtailing citizen recourse to the EPA's dismissal of Del Toral's findings, citizens have grown more skeptical that their government is protecting them. With Flint's story spread more widely, perhaps this skepticism can become a provocation to credential marginalized residents elsewhere when they are confronted with common threats. 
Funding This research received no specific grant from any funding agency in the public, commercial, or not-for-profit sectors.

\section{References}

Adams D (2014a) City to get drinking water from river as pact with Detroit ends. The Flint Journal, 6 March. Available (accessed 28 December 2017) at: http://www.mlive.com/news/flint/index.ssf/2014/03/ flint_drinking_water_to_come_f.html

Adams D (2014b) City shells out $\$ 4$ million on plant since Detroit ended water pact. The Flint Journal, 5 January. Available (accessed 28 December 2017) at: http://www.mlive.com.proxy.lib.umich.edu/news/ flint/index.ssf/2014/03/flint_drinking_water_to_come_f.html

Birkenholtz T (2010) 'Full-cost recovery': Producing differentiated water collection practices and responses to centralized water networks in Jaipur, India. Environment and Planning A 42(9): 2238-2253.

Bosman J, Davey M and Smith M (2016) As water problems grew, officials belittled complaints from Flint. The New York Times, 20 January. Available (accessed 28 December 2017) at: https://www.nytimes. com/2016/01/21/us/flint-michigan-lead-watercrisis.html

Brush M (2015) Expert says Michigan officials changed a Flint lead report to avoid federal action. Michigan Radio, 5 November. Available (accessed 28 December 2017) at: http://michiganradio.org/post/expertsays-michigan-officials-changed-flint-lead-reportavoid-federal-action

Carmody S (2015a) Flint meeting eases few concerns about safety of the city's water. Michigan Radio, 21 January. Available (accessed 28 December 2017) at: http://michiganradio.org/post/flint-meeting-easesfew-concerns-about-safety-citys-water

Carmody S (2015b) Flint officials say city water is safe to drink, but some residents are skeptical. Michigan Radio, 7 January. Available (accessed 28 December 2017) at: http://michiganradio.org/post/flint-officials-say-city-water-safe-drink-some-residents-areskeptical

Copeland C (2012) Water infrastructure financing: History of EPA appropriations. Congressional Research Service, pp. 7-5700. Available (accessed 28 December 2017) at: https://castor.house.gov/uploadedfiles/water_infrastructure_finance_report.pdf

Counts J (2016a) How government failed the people of Flint. The Flint Journal, 24 January. Available (accessed 28 December 2017) at: http://infoweb.newsbank.com/resources/doc/nb/ news/15A98CB5A0665B78?p=AWNB 
Counts J (2016b) It started as a cost-savings move. The Flint Journal, 8 May. Available (accessed 28 December 2017) at:

http://infoweb.newsbank.com/resources/doc/nb/news/15CC241BE2252660?p=AWNB

Del Toral M (2015) High lead levels in Flint, Michigan - interim report. United States Environmental Protection Agency. Available (accessed 28 December 2017) at: flintwaterstudy.org/wp-content/ uploads/2015/11/Miguels-Memo.pdf

Desan MH and Steinmetz (2015) The spontaneous sociology of Detroit's hyper-crisis. In: Smith MP and Kirkpatrick LO (eds) Reinventing Detroit: The Politics of Possibility. Piscataway, NJ: Transaction Publishers, 15-35.

Egan P (2016) Amid denials, state workers in Flint got clean water. Detroit Free Press, 28 January. Available (accessed 28 December 2017) at: https://www.freep.com/story/news/local/michigan/flint-water-crisis/2016/01/28/amiddenials-state-workers-flint-got-clean-water/79470650/

Fasenfest D and Pride T (2016) Emergency management in Michigan: Race, class and the limits of liberal democracy. Critical Sociology 42(3): 331-334.

Fonger R (2014a) State says city river water meets quality standards. The Flint Journal, 23 May. Available (accessed 28 December 2017) at:

http://www.mlive.com.proxy.lib.umich.edu/news/flint/index.

ssf/2014/05/state_says_flint_river_water_m.html

Fonger R (2014b) River water complicates fight against bacteria. The Flint Journal, 19 September. Available (accessed 30 December 2017) at:

http://www.mlive.com/news/flint/index.ssf/2014/09/dpw_director_says_flint_river.html

Fonger R (2014c) GM's water decision to cost $\$ 400 \mathrm{~K}$ annually. The Flint Journal, 16 October. Available (accessed 30 December 2017) at: http://www.mlive.com/news/flint/index.ssf/2014/10/gms_decision_ to_stop_using_fli.html

Fonger R (2015a) Officials say water getting better, but many unsatisfied. The Flint Journal, 21 January. Available (accessed 30 December 2017) at: http://www.mlive.com/news/flint/index.ssf/2015/01/state_water_officials_tell_fli.html

Fonger R (2015b) Head Start stops serving city water to 1,300 preschoolers. The Flint Journal, 5 February. Available (accessed 30 December 2017) at: http://www.mlive.com/news/flint/index.ssf/2015/02/gisd_shuts_off_flint_water_for.html

Fonger R (2015c) Erin Brockovich investigator says tweaks can fix Flint River water. The Flint Journal: Web Edition Articles, 11 February. Available (accessed 30 December 2017) at: http://www.mlive.com/news/

flint/index.ssf/2015/02/erin_brockovich_investigator_s.html 
Fonger R (2015d) Despite quality problems, 'Your water is safe,' says Flint consultant. The Flint Journal: Web Edition Articles, 19 February. Available (accessed 30 December 2017) at: http://www.mlive.com/ news/flint/index.ssf/2015/02/flint_consultant_tells_city_de.html

Fonger R (2015e) Flint water committee meets, but some residents don't see progress. The Flint Journal: Web Edition Articles, 19 March. Available (accessed 30 December 2017) at: http://www.mlive.com/news/

flint/index.ssf/2015/03/flint_water_committee_meets_bu.html

Fonger R (2015f) Lead leaches into 'very corrosive' Flint drinking water, researchers say. The Flint Journal: Web Edition Articles, 2 September. Available (accessed 30 December 2017) at: http://www.mlive.com/ news/flint/index.ssf/2015/09/new_testing_shows_flint_water.html

Fonger R (2015g) Elevated lead found in more Flint kids after water switch, study finds. The Flint Journal: Web Edition Articles, 24 September. Available (accessed 30 December 2017) at: http://www.mlive.com/ news/flint/index.ssf/2015/09/study_shows_twice_as_many_flin.html

Gibbs L (2002) Citizen activism for environmental health: The growth of a powerful new grassroots health movement. Annals of the American Academy of Political and Social Science 584(1): 97-109.

Guyette C (2015a) Independent water tests show lead problems far worse than Flint claims. Detroit MetroTimes, 1 September. Available (accessed 30 December 2017) at: https://www.metrotimes.com/ news-hits/archives/2015/09/01/independent-water-testsshow-lead-problems-far-worse-than-flintclaims

Guyette C (2015b) Scary: Leaded water and one Flint family's toxic nightmare. Deadline Detroit, 9 July. Available (accessed 30 December 2017) at:

http://www.deadlinedetroit.com/articles/12697/scary_ leaded_water_and_one_flint_family_s_toxic_nightmare\#.Wkfor1Q-dZ0

Hayes G (2017) Regimes of austerity. Social Movement Studies 16(1): 21-35.

Jackson DZ (2017) Environmental justice? Unjust coverage of the Flint water crisis. Shorenstein Center on Media, Politics and Public Policy. Available (accessed 30 December 2017) at: https://shorensteincenter. org/wp-content/uploads/2017/07/FlintWater-Crisis-Derrick-Z-Jackson-1.pdf

Lee SJ, Krings A, Rose S, et al. (2016) Racial inequality and the implementation of emergency manager laws in economically distressed urban areas. Children and Youth Services Review 70: 1-7. 
Longley K (2011) River vs. lake. The Flint Journal, 23 January. Available (accessed 30 December 2017) at:

http://www.mlive.com/news/flint/index.ssf/2011/01/water_pipeline_vs_flint_river.html

Longley K (2012) New big three-in water? The Flint Journal, 13 May. Available (accessed 30 December 2017) at:

http://www.mlive.com/news/flint/index.ssf/2012/05/flints_future_drinking_water_c.html

Lurie J (2016) Meet the mom who helped expose Flint's toxic water nightmare. Mother Jones, 21 January. Available (accessed 30 December 2017) at:

http://www.motherjones.com/politics/2016/01/motherexposed-flint-lead-contaminationwater-crisis/

Lynch J and Ramirez C (2016) Karegnondi water system rooted in frustration. Detroit News, 24 March. Available (accessed 30 December 2017) at:

http://www.detroitnews.com/story/news/michigan/flintwater-crisis/2016/03/24/kwapipeline-flint-water/82237222/

Nagl K (2015) Flint Coalition for Clean and Safe Water prepares legal action against city. MLive, 16 April. Available (accessed 12 October 2017) at: http://www.mlive.com/news/flint/index.ssf/2015/04/flint_coalition_for_clean_and.html

Olson T (2016) The science behind the Flint water crisis: corrosion of pipes, erosion of trust. The Conversation. Available (accessed 1 September 2017) at: http://theconversation.com/the-science-behind-the-flintwater-crisis-corrosion-of-pipeserosion-of-trust-53776

Peck J (2012) Austerity urbanism. City 16(6): 626-655. Schuch S (2015) UM-Flint: Water on campus mostly safe. The Flint Journal, 10 February. Available (accessed 30 December 2017) at: http://www.mlive.com/news/flint/index.ssf/2015/02/water_testing_at_um-flint_ show.html

Scorsone EA (2014) Municipal fiscal emergency laws: Background and guide to statebased approaches [Working Paper No. 14-21], Arlington, VA: Mercatus Center at George Mason University.

Smith L (2015) Leaked internal memo shows federal regulator's concerns about lead in Flint's water. Michigan Radio, 13 July. Available (accessed 30 December 2017) at: http://michiganradio.org/post/ leaked-internal-memo-shows-federal-regulator-s-concernsabout-lead-flint-s-water

Smith L (2016a) After blowing the whistle on Flint's water, EPA 'rogue employee' has been silent. Until now. Michigan Radio, 21 January. Available (accessed 30 December 2017) at: http://michiganradio.org/ post/after-blowing-whistle-flints-water-epa-rogueemployee-has-been-silent-until-now 
Smith L (2016b) Do not drink: The water crisis in Flint, Michigan. Reveal. Available (accessed 29 August 2016) at: https://www.revealnews.org/episodes/do-not-drink-thewater-crisis-in-flint-michigan

Smith M (2015) A water dilemma in Michigan: Cloudy or costly? The New York Times, 24 March. Available (accessed 30 December 2017) at:

https://www.nytimes.com/2015/03/25/us/a-water-dilemma-in-michigan-cheaper-orclearer.html?_r=0 S

mith M (2016) As Flint fought to be heard, Virginia Tech team sounded alarm. The New York Times, 6 February. Available (accessed 30 December 2017) at:

https://www.nytimes.com/2016/02/07/us/as-flintfought-to-be-heard-virginia-tech-teamsounded-alarm.html

Spangler T (2016) E-mails shed light on EPA's role in Flint water crisis. Detroit Free Press, 5 March. Available (accessed 30 December 2017) at:

https://www.freep.com/story/news/local/michigan/flintwater-crisis/2016/03/05/e-mailsshed-light-epas-role-flint-water-crisis/80576406/ 